\title{
O cotidiano dos escravos em Antonina
}

\author{
Sílvia Correia de Freitas ${ }^{1}$
}

\begin{abstract}
Cada instância do social apreende um aspecto particular das mudanças e permanências históricas e o expressa de uma determinada maneira. É através da complexidade da relação entre vários discursos do passado e o do historiador que se situa a possibilidade de fazer história, de construir o saber histórico. Não se trata, portanto, de restituir simplesmente o que foi dito no passado privilegiando um discurso, seja ele qual for, contra outro. Mas, sim, de verificar sua condição de verdade- especifica- enquanto um discurso oriundo de uma parte do social, que não è único ou harmônico e que nos oferece uma (não a única) visão de seu próprio mundo. ${ }^{2}$
\end{abstract}

Depois de visitar algumas vezes Antonina e de conversar com muitas pessoas, acabei por encontrar estes documentos, os processos criminais, que muitos me falaram que nem existiam mais. Eles estavam esquecidos no fundo de uma despensa no Fórum Luis Silva e Albuquerque, misturados a muitos produtos de limpeza, vassouras, lâmpadas queimadas e revistas pornográficas. A princípio 0 trabalho foi braçal, retirar todo o entulho que estava na frente para poder chegar até os processos e retira-los daquele lugar apertado e poeirento. Mas, quando comecei a lê-los, percebi que o trabalho não tinha sido em vão!

Os processos criminais nos permitem uma aproximação com a fala escrava, mesmo que filtrada pela pena do escrivão. Esta é uma documentação que, a parte dos objetivos pelos quais foi criada, ilumina o registro do cotidiano. Ela mostra-se extremamente rica no sentido de oferecer não apenas o discurso de senhores, agregados, negociantes e lavradores, mas igualmente dos escravos a respeito de um mesmo acontecimento.*

Esta documentação mostra-se muito útil no sentido de possibilitar uma descrição densa, proposta por Geertz. Ela permite o entendimento do que as declarações poderiam ter de significado para as pessoas que as formularam.

A partir destes processos criminais podemos ter acesso às versões e visões do escravo sobre a escravidão. Eles apontam para o fato de que a liberdade era uma causa dos negros, uma luta com significados propriamente populares, sendo que estes significados eram elaborações culturais próprias.

O direito foi um campo de batalha decisivo para o fim da escravidão e não se justifica o desdém ou o mecanismo que a historiografia habitualmente dispensa a esse tema. ${ }^{3} \mathrm{Na}$ verdade, mesmo neste jargão legal, cujo objetivo é o de calar a vós do escravo e falar por ele, nota-se que os negros conseguiram colocar, ao menos em parte, certos direitos conquistados e consagrados pelo costume, da mesma forma que conseguiram o que consideravam um cativeiro justo ou ao menos tolerável.

1 Graduação - História/UFPR (Mestrado - História/UFSC).

2 LARA, S.H. Campos da violência: escravos e senhores na Capitania do Rio de Janeiro, 1750-1808. Rio de Janeiro: Paz e Terra, 1988, p.22.

* Ao longo de todo texto, os documentos de época são transcritos respeitando-se sempre a pontuação e a gramática originais, mas atualizando-se a ortografia das palavras.

3 CHALHOUB, S. Visões da liberdade: uma história das últimas décadas da escravidão na Corte. São, Paulo: Companhia das Letras, 1990, p.172 
Um leitor mais desatento pode imaginar que estas fontes são muito perigosas pelo fato de as testemunhas estarem mentindo, mas cabe a eles lembrar que a mentira nada mais é do que um jogo social, portanto, elas são igualmente repletas de significados a serem interpretados, que podem nos dizer muitas coisas, assim como a verdade.

A minha opção foi o caminho que leva do particular ao geral. Privilegiei, em meu trabalho, como local a cidade de Antonina no período que vai do ano de 1859 até 1870. Então, vamos a Antonina para mergulharmos num mundo de muitas histórias e pessoas, para demonstrar e remontar práticas, discursos, estratégias e relações que se fizeram e se desfizeram no cotidiano, recuperando movimentos e projetos de homens e mulheres que, afinal, teceram a história e construíram muitas visões. Para tal, pretende-se ultrapassar a dicotomia entre paternalismo e violência, passar a notar como a relação senhor-escravo construía-se cotidianamente como uma relação pessoal de dominação onde encontravam-se presentes confrontos, resistências e acomodações, solidariedades e várias tensões.

O exame de crimes, dos criminosos e suas vítimas, e do cruzamento entre as diferentes instâncias repressivas, nos permitirá aprofundar a análise dos confrontos e conflitos que envolviam escravos e iluminar outros aspectos da relação senhor-escravo em Antonina. Muitos papéis sumiram, devorados pelas traças, apagados pelas águas e bolores ou meramente perdidos pelo descuido e descaso com a documentação, que nem mesmo arquivada está. Minha intenção não é realizar um estudo sobre a criminalidade em Antonina, mas dar luz a outros aspectos das tensões, conflitos e confrontos que envolviam senhores e escravos. Para isto, realizei alguns recortes privilegiando os processos que se referiam diretamente a escravos. Olhar através desta renda, procurar os fios no claro-escuro dos documentos e refazer alguns desenhos semi-apagados para poder reconstruir certas tramas da história.

A discussão que põe em questão o caráter brando ou cruel da escravidão no Brasil já existe de longa data na historiografia e apresenta variadas imagens que vão desde a formação da figura de um senhor benevolente e justo com seus escravos fiéis e submissos até a inexistência de referência a qualquer manifestação de rebeldia escrava no Brasil da época colonial. Mesmo com as diferentes facetas, vinculadas a diferentes propostas ideológicas e políticas, a relação entre violência e escravidão é inerente a todo conjunto da bibliografia.

\section{Castigo justo ou injusto? Abrem-se brechas para o escravo resistir.}

É inegável a importância que o castigo possuía no efetivo funcionamento da escravidão. Mesmo que parcelado, regulamentado e aliviado, seria impossível ele deixar de existir. O castigo deveria ensinar o escravo sem o perigo de perdê-lo, pois tratava-se de um investimento. Os castigos freqüentes ou em demasia poderiam acarretar em fugas ou suicídio. No Brasil colonial a pedagogia do castigo se ligava à própria idéia de ordenação e regulamentação da escravidão. A historiadora Silvia Lara coloca ainda que

O "governo econômico dos senhores" nada mais era, portanto, que o equilíbrio entre produção 
lucrativa, sobrevivência do escravo e continuidade da dominação senhorial. Muito trabalho, alimento suficiente para sobrevivência e castigo medido: eis os elementos que compunham a economia senhorial no governo dos escravos. Mas, sem dúvida alguma, era o castigo- a violência física sabiamente ministrada pelo senhor- que garantia a continuidade da relação de produção... ${ }^{4}$

O castigo aceito pela sociedade era um castigo justo e corretivo, portanto, não deveria ser aplicado sem motivos e tinha um caráter eminentemente corretivo. Dois aspectos muito importantes não podem ser esquecidos em relação ao castigo: o senhor não poderia perder de vista que o escravo representava um investimento, portanto, matar um escravo significava perder um investimento; e o castigo deveria ser eficaz e educativo. Em suma, castigar era uma tarefa fundamental da condição senhorial. Surge, então, uma questão crucial:

\begin{abstract}
era direito do senhor castigar seu escravo, mas, por outro lado, a Coroa tinha a necessidade de controlar este direito...Contudo, ao fazê-lo, promovia um desequilíbrio na relação senhor-escravo: repreender o senhor, puni-lo, significava também questionar seu poder...Assim, sem questionar o castigo dos escravos em si, mas problematizando os abusos e excessos, a Coroa insistia na tecla da moderação: com isto, visava a mais que adequar a prática senhorial a preceitos humanitários... Ao mesmo tempo, porém, não se podia restringir este poder sem perturbar a relação senhor-escravo: abria-se aí uma brecha legal para as reivindicações dos castigos, que incidiam diretamente no controle da dominação senhorial. ${ }^{5}$
\end{abstract}

Desta maneira, sem contestar a escravidão, muito pelo contrário, a Coroa procurava resolver tanto o problema dos castigos quanto a conseqüente rebeldia dos escravos.

Podemos concluir que o castigo físico dos escravos em nenhum momento foi contestado pela sociedade. Condenou-se os seus excessos, mas jamais foi proposta a sua abolição. No Brasil colonial, tanto a Igreja como senhores e escravos não contestavam a sua existência, porém cada um tinha sua visão diferenciada da sua função e delimitação. O castigo exemplar não foi uma invenção dos senhores coloniais. Ele fazia parte do mundo moderno tanto da Metrópole quanto da Colônia. O castigo físico, medido, justo, corretivo, educativo, moderado e exemplar dos escravos mantinha sua especificidade: exercício do poder senhorial e reafirmação da dominação. Sua ação era disciplinadora, não só porque era um meio para ordenar o trabalho, dividi-lo e regulá-lo, mas também porque marcava, nos escravos, as regras de sua submissão, de sua condição de seres submetidos a uma dominação e exploração particulares. Ele não foi apenas punitivo, mas esteve voltado para o futuro, prevenindo rebeliões, mantendo e conservando os escravos, enquanto escravos, continuamente.

A alegação de crueldade do senhor poderia, de acordo com as Cartas Régias do final do século XVII, dar origem a uma troca de senhor ou a uma ação de liberdade. Neste sentido,

O recurso ao poder público se fazia, pois, no sentido da preservação de um equilíbrio de poderes entre os senhores, assentado numa certa homogeneidade de conduta desses senhores em relação a seus escravos. (...) A instância judicial constitui-se, nesses embates, como mediação entre esses interesses, como o lugar onde tais alianças podiam se concretizar. Nesse sentido, a Justiça podia ser vista pelos senhores tanto como um recurso possível em suas lutas locais quanto como

4 Op. cit., Campos da violência..., p. 56.

5 Ibid., p. 66.

Qevista Q \ernáculo 
algo de que era necessário defender-se, pois tornava público o que era particular. ${ }^{6}$

$\mathrm{Na}$ verdade abriam-se brechas para o questionamento escravo do domínio senhorial. Muitos escravos recorriam a polícia para queixarem-se dos maus tratos de seus senhores.

Era o ano de Nascimento do Nosso Senhor Jesus Cristo de 1859, aos 29 de junho do mesmo ano, nesta cidade de Antonina, na Delegacia de Polícia desta mesma cidade. Foi aberto um processo contra o senhor Corrêa pelo seu escravo Diogo que encontrava-se preso na cadeia para examinarem o seu estado. Diogo queixava-se estar com uma costela fraturada e um braço bastante machucado. Os presos da cadeia disseram que o escravo deitava sangue pelo nariz e pela boca, que não podia se mover e que estava prestes a morrer. ${ }^{7}$

Todas as testemunhas, em sua maioria negociantes e lavradores moradores de Antonina, acabam dizendo que o escravo havia apanhado de seu senhor por motivo justo, e que não houvera o excesso de castigo. Infelizmente Diogo não é interrogado, mas somente o fato dele ter corrido até a cadeia para dar queixa contra o seu senhor já nos permite observar que, longe de estar conformado com a situação, Diogo estava aproveitando-se das brechas do sistema para lutar por um cativeiro mais justo. Pois, como se sabe, os escravos que eram castigados injustamente ou demasiadamente por seus senhores, muitas vezes tinham o direito de serem vendidos a outros senhores ou a ações de liberdade. Assim podemos perceber que não foi à toa que Diogo buscou o apoio da Delegacia de Polícia. A referência a castigos excessivos era provavelmente a forma de um escravo traduzir para a linguagem dos senhores a sua compreensão mais geral de que direitos seus não estavam sendo considerados ou respeitados.

É extremamente interessante analisar o discurso da autoridade quanto ao castigo na figura do Promotor Público de Paranaguá Francisco Ferreira Corrêa em relação ao ocorrido

Não posso nem devo mostrar-me estranho a um processo que ataca profundamente a base e os
princípios que regem a nossa cidade. É duro decerto que um escravo seja desumanamente casti-
gado por seu senhor, que tal direito não tem, mas provado como no caso presente, que o espan-
camento não foi brutal, que o corretivo consistiu em um castigo moderado, o que é permitido no
parágrafo $26^{\circ}$ do artigo 16 do Código Criminal, atentando-se a que a matéria dos autos é por sua
natureza muito melindrosa, e que acima de um exame perfunctório e incompetente esta o valioso
juízo de dois profissionais, que atestam à folha 13, que o escravo Diogo não tinha fraturas, nem
sinal algum que o pudesse denotar, sendo que este exame foi procedido ontem, cinco dias depois
do acontecimento que originou este processo, atendendo-se finalmente que as testemunhas não
fossem carga ao indiciado, e que não se procedeu o corpo delito regular ou propriamente dito,
sou de opinião que não deve ser o indiciado pronunciado, tanto porque o procedimento contrário
ficaria com um precedente que acarretaria consequências de desrespeito e insubordinação dos
escravos para com seus senhores. ${ }^{8}$

Aqui cabe uma questão fundamental: de que maneira as formas de relação dos escravos com os representantes e os espaços do poder público interferi-

6 Ibid., p. 334-335.

7 Fórum Luis Silva e Albuquerque . Auto crime. Réu : Antônio Corrêa. Autor : Justiça. Ano : 1859, maço: 18501860.

8 Ibid., p.6.

88

Qevista \$ernáculo 
ram no espaço de dominação escravista do séc. XIX? A hipótese é que a partir de meados do século passado uma quantidade significativa de escravos passou a impor limites bem precisos às atitudes mais agressivas de dominação senhorial, por meio de fugas para as delegacias públicas ou cadeias, onde eram "depositados" até ser resolvida a situação com seus senhores. Essa atitude, somada a outros fatores, contribuiu para que em muitos casos as autoridades policiais e jurídicas estivessem ao lado da causa dos escravos, mesmo não sendo essa a sua intenção. A preocupação das autoridades com o estado dos castigos não teve raízes humanas ou morais. Ela, antes de mais nada, visava a manutenção da ordem e a tranqüilidade da província. Não podemos esquecer que muitas vezes os escravos que recorriam às autoridades ainda corriam o risco de apanhar nas cadeias e delegacias, mesmo sendo isso proibido pela lei. Devemos ter em mente que essa é uma proibição que foi muito violada. Esta é uma atitude que perdura até o presente. Se olharmos hoje para a realidade do país veremos pessoas que são espancadas e em alguns casos assassinadas pela polícia por cometerem pequenos delitos ou até mesmo por uma causa inexistente.

Para a segunda metade do séc. XIX há várias evidências de uma constante busca dos escravos por espaços públicos da polícia e da lei. Spiller Pena localiza em Curitiba negros que iam até a cadeia para dar queixa dos excessos de castigos de seus senhores, exigindo a sua liberdade imediata ou a transferência para outro senhor de sua preferência. Analisando a Corte, Chalhoub encontrou igualmente este comportamento reivindicatório dos escravos. Mas, evidentemente, isto não pode ser absolutizado.

$\mathrm{Na}$ realidade, este triplo encontro entre senhores, escravos e poder público era repleto de contradições e ambigüidades. Realmente alguns senhores aceitavam a ação policial encarando-a como exemplar, porém, outros viam-na como uma intromissão em seus negócios. Desta maneira o poder público apresentou dois comportamentos distintos em relação à questão da escravidão: em alguns momentos foi um aliados das causas senhoriais, estando disponível para a captura de escravos fugitivos ou para a aplicação de castigos ponderados em escravos que se comportavam mal; em outros interferiu na própria pratica de dominação. O poder público pode ter evitado a explosão de revoltas e rebeliões que colocariam em perigo a paz e tranquilidade provincial por um lado, mas por outro acabou abrindo uma brecha para os próprios cativos enfrentarem seus senhores.

A atitude de fuga dos escravos para espaços públicos deve ser encarada muito mais como resultado da luta dos escravos por sua visão de um cativeiro justo, e não como um comportamento receptivo por parte dos agentes policiais. Tendo em vista este processo que envolve Diogo, devemos perceber que estamos diante de uma situação onde um escravo tomou uma atitude diante do que achava injusto por parte de seu senhor. Esta atitude ilustra bem a pressão política de um escravo no processo gradual de descrença do sistema que os escravizava, ou ao menos, da criação de parâmetros do que seria uma "economia moral" da escravidão desta época.

Encontrei um outro processo, do ano de 1859, referente a um escravo castigado, só que neste caso o agressor não é seu proprietário, mas um padeiro que se encontra na casa de Luis Manoel da Cunha, para quem Jesuino Amado do 
Nascimento (o proprietário) havia alugado seu escravo Simão. ${ }^{9}$

Manoel Antonio de Mello, 30 anos, negociante, casado, morador desta cidade e natural da mesma testemunha que (...) estando na porta de sua casa de negócios vinha passando o preto Simão escravo do queixoso e que ele testemunha perguntou o que é que ele tinha por o ver com um braço atado então é que o escravo Simão Ihe dissera que o padeiro que estava em casa do Sr. Luis Manoel da Cunha lhe havia dado umas pancadas $(. . .)^{10}$

Uma outra testemunha do processo, Luis Belicio da Silva Bastos, 28 anos, padeiro, casado, morador desta cidade e natural de Portugal diz que

(...) nove horas da noite mais ou menos chegou em casa de Manuel Antonio de Mello onde ele testemunha mora. O escravo mulato Antonio do Alferes Antonio José Alves disse-lhe que naquele instante o preto Simão que está alugado (...) acabava de apanhar de Geronimo Fernandes Braga e que noutro dia ele ouviu da boca do mesmo prelo Simão e que the mostrou uma mão machucada $(. . .)^{11}$

A validade desta testemunha é colocada em questão devido a mesma ser inimiga do acusado, isso é recorrente em vários processos que examinei.

Outra testemunha, João Correia de Freitas, 21 anos, negociante, solteiro, morador desta cidade e natural de Paranaguá, fala que

(...) na madrugada do dia 6 o acusado indo acordar o preto Simão que estava alugado em casa de Luis Manoel da Cunha o mesmo preto o desatendera e então é que ele acusado deu-lhe duas bofetadas e levantamdo-se Luis Manoel da Cunha perguntou ao acusado que barulho era aquele ele respondeu que o preto o havia desobedecido e então foi que Luis Manoel da Cunha disse que metesse-lhe o pau por sua conta e sendo perguntado de que maneira o preto o havia desobedecido ao acusado por ele testemunho foi dito que foi em não querer levantar-se da cama em que estava deitado e que isto ela testemunha ouviu do acusado $(. . .)^{12}$

A testemunha informante Serafião Manoel Gomes, 15 anos mais ou menos, que vive de suas agências, morador desta cidade e natural de Paranaguá informa que

(...) indo Jeronimo Fernandes Braga acordar o preto Simão e mais o criolo Jorge para irem trabalhar na massadeira da padaria Jorge acordou-se e Simão custou a acordar-se e depois de acordado sentou-se na esteira em que dormia e principiou a coçar-se então é que o acusado disse a ele que ia coçar e pegou um cabo de vassoura e deu-lhe poucas bordoadas e então levantou-se e encostou-se na chaminé da cozinha e não quis trabalhar e acordando-se Luis Manoel da Cunha perguntou que barulho era aquele. Respondeu o acusado que o preto não queria trabalhar e queria ir-se embora para a casa de seu senhor porque estava com um braço machucado. Disse ao acusado o Mesmo Luis Manoel da Cunha que metesse-Ihe o pau por sua conta e depois de ter apanhado sai para não voltar mais $(. .)^{13}$

Foi então feito um interrogatório ao acusado Jeronimo Fernandes Braga, natural de Portugal, morador desta cidade a cinquenta dias mais ou menos,

9 Fórum Luis Silva e Albuquerque. Auto crime. Réu: Geronimo Fernandes Braga. Autor: Jesuino Amado do Nascimento. Ano : 1859: maço 1850-1860.

10 Ibid., p. 11.

11 Ibid., p. 12.

12 Ibid., p. 14.

13 Ibid., p. 15.

90

Qevista Xernáculo 


\begin{abstract}
Perguntado se ele tinha fatos a alegar ou provas que justifiquem ou mostrem sua inocência. Respondeu que era verdade ter dado algumas bordoadas no preto Simão para poder se defender dele por o ter se arremessado com fúria para ele acusado na ocasião em que foi acordar as dez e meia da noite para vir trabalhar na massadeira em que faria o pão e estando muito tempo a chamar para que se levantasse nem ao menos Ihe respondia ao chamado (...) e indo Ihe acordar pela Segunda vez acordado disse-lhe que se não levantasse lhe faria levantar, foi então que sem que sentou-se na esteira em que dormia e não tratava de por-se em pé e repetindo o acusado a ele Simão que se pusesse em pé teve em resposta ao preto dizer-Ihe não e deu-Ihe nesta ocasião uma bofetada, foi quando o preto se dirigiu contra o acusado com fito talvez de o maltratar, nesta ocasião encontrando uma vassoura deu-lhe com ela e o tendo Luis Manoel da Cunha observado o barulho perguntou o que era aquilo, contando o acusado o ocorrido mandou o mesmo Luis Manoel da Cunha o preto para que fosse trabalhar, teve em resposta que não trabalhava porque ia para a casa de seu senhor e que sua senhora the tinha dito que não aguentasse desaforo (...) e lá não se demorou e retirando-se para a casa de seu senhor. ${ }^{14}$
\end{abstract}

Na conclusão deste processo o réu é acusado. Mas o que é interessante notar é a postura do escravo diante das ordens de um outro senhor que não era o seu. Ele se nega a trabalhar por considerar um desaforo acordarem-no aquela hora, que era seu momento de descanso, para ir trabalhar na massadeira, e ainda por cima é castigado. Uma interpretação válida para este caso é que este castigo não poderia ser considerado justo pelo escravo pelo simples fato dele ter sido aplicado por outrem e não pelo seu senhor. O escravo deixou bem clara a sua insatisfação e seu posicionamento diante da situação tendo se negado a trabalhar e ainda dirigindo-se para a casa de seu senhor...

O castigo físico dos escravos fazia parte do governo econômico dos senhores como exercício de dominação, instrumento de controle e disciplina da massa escrava, preventivo de rebeldias. Desta forma, equilibrava produção lucrativa, sobrevivência do escravo e continuidade da dominação senhorial. Não se tratava, porém, de qualquer castigo, mas sim de um castigo físico moderado, medido, justo, corretivo, educativo e exemplar. Era assim que ele aparecia na fala dos senhores e até mesmo na fala dos próprios escravos, como algo incontestado, natural. Nota-se, ainda, que a prática do castigo senhorial continha uma dimensão pedagógica que unia amor e medo, mercê e rigor, e se fazia no interior de uma relação pessoal de dominação que, através de suas mediações, possibilitava um afastamento senhorial do exercício direto dos excessos e abusos.

$\mathrm{Na}$ verdade, se o castigo físico não fosse encarado como parte de um esforço educativo, ninguém o teria aceitado em momento algum, nem os senhores, tampouco os escravos. Neste sentido Chalhoub faz uma colocação muito interessante chamando a atenção para a importância de se fazer uma comparação entre o castigo, nos tempos da escravidão, e o acidente de trabalho, hoje, como disciplinadores e mutiladores do corpo do trabalhador:

\footnotetext{
Se todos entendessem os 'acidentes de trabalho' de hoje em dia como violência, nós não seriamos capazes de viver uma realidade capitalista. A chicotada era, num certo sentido, o 'acidente de trabalho' na escravidão: se o trabalhador não se comportasse de uma forma determinada, o 'acidente' acontecia. Assim, hoje em dia, quando ocorre qualquer tragédia numa situação de trabalho, os patrões e seus técnicos concluem logo que houve 'falha humana'. Milhares e milhares de 'acidentes' ocorrem a cada hora por falha humana'. Foi o trabalhador que não andou direito. Está ainda para ser feito um estudo comparativo entre o chicote e a máquina enquanto instrumentos de disciplinarização e mutilação do corpo do trabalhador. Quanta sutileza hoje em dia... mas tudo
} 
Desta maneira, atribuir uma noção geral de violência à prática do castigo físico significa não levarem conta que o seu significado era produzido no interior e no decorrer das relações sociais específicas. O discurso que evidencia a violência acaba por igualar-se ao que insiste na tecla da coisificação do escravo. Ao conceberem a resistência escrava apenas quando ela rompe a relação de dominação, quando os escravos tentam deixar de ser cativos, acabam ambos também por negar-lhes, enquanto cativos, sua condição de agentes históricos. ${ }^{16}$

$\mathrm{Na}$ ótica senhorial, existem exemplos de que algumas leis mais severas, como a proibição do ajuntamento de escravos em festas, ${ }^{*}$ que não foram respeitadas na prática. Isto traz à tona um paradoxo, porque estes dispositivos legais foram elaborados de acordo com a própria concepção dos proprietários de escravos, tendo em vista assegurar o exercício da dominação. Mas muitas vezes estas leis não foram seguidas à risca pelos senhores exatamente para evitar situações de tensão nas relações com seus escravos. Desta maneira, segundo Spiller

\begin{abstract}
o ajuntamento de negros libertos e escravos em coligadas, batuques e fandangos foi por vezes permitido pelos proprietários sob determinadas circunstâncias, entre elas, como momento de compensação frente à jornadas árduas e penosas de trabalho; como válvula de escape para situações eminentes de conflito e até mesmo como uma atividade para ocupar os escravos em períodos de longa inatividade. A realização de lais eventos, foi contudo, muito bem controlada. Os escravos que desejassem se divertir deveriam, em primeiro lugar, pedir a permissão para seu proprietário. Concordando com a solicitação, o senhor fornecia o dinheiro para que os cativos pudessem pagar a licença na secretaria da polícia para a realização do festejo. Além deste árduo e custoso caminho para a diversão, os escravos ainda tinham que suportar a ' presença de policiais que se encarregavam de manter a ordem durante o tempo "livre" da festa. ${ }^{17}$
\end{abstract}

Alguns senhores não cumpriam os dispositivos legais que proibiam o acesso de armas aos escravos. A pratica da legislação ocorria de acordo com as necessidades senhoriais. Se em determinados momentos sua prática foi desprezada, em outros ela apareceu com força total para garantir a própria continuidade do sistema escravista. A utilização de armas pelos escravos parece muitas vezes ter sido natural, principalmente quando seu uso era justificado por tarefas de deu oficio.

Este é o caso do escravo Teles que foi preso porque andava armado com uma faca de ponta. No interrogatório feito pela polícia Teles falou que era morador da Província de Minas Gerais e que viera para Antonina em companhia de seu senhor, mas que fazia um dia que o mesmo havia seguido para o Rio de Janeiro e que ele e um outro companheiro ficaram entregues ao senhor Mourão da Silveira. Quando Ihe foi perguntado por que carregava uma faca, respondeu que a faca que trazia consigo o feitor da Estrada da Graciosa Ihe havia dado para cortar

15 CHALHOUB, S. Visões da liberdade: senhores, escravos e abolicionistas da Corte nas últimas décadas da escravidão. In: História: questões e debates. Curitiba, n¹6, junho. 1988, p.21-22.

16 Op. cit., Campos da violência..., p. 345.

* O artigo 85 do título X (sobre vozerias e alarias) da lei no 79, de 11 de julho de 186 1, das posturas, estabelecia a proibição para o caso de juntar-se dentro da povoação, nas ruas, praças ou dentro de casa, escravos com tambores e cantarias. Spiller, p. 137.

17 Op. cit., O jogo da face..., p. 37-38.

92

Qevista Qrernáculo 
o mato (...) e que o feitor se chamava Bruno de Melo. ${ }^{18}$ Foi-lhe ainda perguntado pelas autoridades o que mais fazia nesta estrada e nesta cidade e por que motivo mostrava tanto empenho em querer falar com o Delegado, ele respondeu que (..) falar com o doutor Delegado foi para saber se o Senhor Manoel Ferreira Lopes tinha feito alguma queixa dele respondente, e que tinha vindo buscar mantimentos para a Estrada, a mando do administrador da mesma Estrada. ${ }^{19}$ Foi-lhe perguntado finalmente a quanto tempo estava trabalhando na estrada, a resposta de Teles foi que trabalhava a mais ou menos um ano.

Em um depoimento, um dos soldados de polícia responsáveis pela prisão de Teles fala:

\begin{abstract}
Chegando o carcereiro desta cidade Domingos Serapio Ferreira na esquina da casa de V.Sa achando um preto de nome Teles, sentado, perguntou o dito carcereiro o que ele queria respondeu-lhe que estava a espera do Senhor Delegado que Ihe queria falar, ao mesmo tempo levantouse o dito preto e como estivesse com uma faca grande de ponta cabo branco com bainha na cintura por baixo da camisa o carcereiro foi lhe tomar a dita faca e ele não a querendo entregar eu e meu camarada observando isso nos aproximamos para lá e demos vós de prisão para o dito preto ele nos escapou e determinou (sic) a correr para o lado do taboão, eu corri com o meu camarada e alcançamos o preto e recolhemos à cadeia. ${ }^{20}$
\end{abstract}

Assim, Teles é recolhido à cadeia de Antonina por ter sido encontrado com uma faca de ponta que Ihe foi arrancada pelos guardas policiais. A primeira testemunha do processo é Domingos Serafim Ferreira, 22 anos, solteiro, natural e morador de Antonina, ele fala que

O preto Teles estava sentado na porta do Delegado. Perguntando ela testemunha o que estava fazendo ali sentado respondeu-lhe o mesmo preto que estava esperando o Delegado Para falar com ele, então indo o preto a procura do mesmo Delegado o encontrou em casa de Antonio e então ela testemunha viu que o preto voltou a casa do Delegado e este vinha atras dele, e ele testemunha estando na esquina do mesmo Delegado observou que o preto estava com uma faca de ponta em baixo da camisa e que avançando para cima do preto a tomou no mesmo instante em que ele testemunha linha tomado a faca o mesmo Delegado deu ordem de prisão ao preto e que este deu de avançar para o lado do mesmo Delegado mas que estando já seguro por ele testemunha mais dois policiais nada se deu, e tratou de correr escapando-se dos que o seguravam mas que logo foi segurado pelos policiais. Perguntado se ela testemunha sabia se este preto costumava andar armado. Respondeu que dias antes ela testemunha estando em frente a casa de Manoel Ferreira Lopes, ouviu algumas pessoas dizerem que o preto Telles estava com uma faca, mas que ela testemunha não viu, mas que nesta ocasião o mesmo Ferreira Lopes dirigiu-se a casa do Delegado a dar parte deste fato. ${ }^{21}$

As outras testemunha vão confirmar o que Domingos Serafim Ferreira testemunhou. O escravo Teles foi condenado a trinta dias de prisão e uma multa que deveria ser paga por seu senhor. Porém durante todo o tempo em que Teles ficou preso ninguém foi reclamá-lo. É feita então uma nova intimarão ao réu, ele fala novamente que é crioulo natural de Minas, que tem 40 anos, que era escravo do senhor Valente e que estava entregue ao senhor Romão. Mas desta vez quando perguntaram onde se acha o senhor Valente, ele respondeu que não sabia. Quando lhe perguntaram onde trabalhava respondeu que no cais novo e depois com o

18 Fórum Luis Silva e Albuquerque. Auto crime. Réu : Teles. Autor : Justiça. Ano: 1869, maço: 1860-1870.

19 Ibid., p. 2.

20 Ibid., p. 6.

21 Ibid., p. 10.

Qevista §ernáculo 
senhor João Christovão e na Estrada com o senhor Juca Carneiro e que ignorava o quanto ganhava no cais, e em casa do senhor João Christovão mas que na Estrada ganhava vinte mil réis por mês. ${ }^{22}$ Foi-lhe ainda perguntado quem recebia seus jornais e quem o sustentava na prisão, Teles respondeu que era o senhor Romão.

Tendo em vista a declaração do réu, e tendo finalizado o tempo de sua prisão, as autoridades intimam Romão para vir receber o réu. O processo fecha-se desta maneira, mas não podemos saber se o senhor Romão realmente dirigiu-se até a cadeia para receber o escravo, tampouco por que motivo ele não fora até então buscar Teles na cadeia, afinal de contas já havia se passado pelo menos trinta dias desde a sua ordem de prisão. É muito interessante também analisar o fato de Teles ter se dirigido ao Delegado para lhe falar, apesar de não ter ficado muito clara a sua intenção. Mas, na verdade, não é isto o que realmente nos interessa. A atitude de Teles evidencia novamente um escravo em busca da autoridade. Fica muito claro igualmente neste processo o medo que girava em tomo da possibilidade de um escravo andar armado.

Outra questão que fica muito clara neste processos é a grande mobilidade que um escravo podia ter em determinadas situações, afinal de contas Teles deve ter caminhado muito pelo mato quando se deslocava do seu local de trabalho (a Estrada da Graciosa) até Antonina. Segundo Silvia Lara

\footnotetext{
Tudo indica que a circulação dos escravos fora das unidades de produção não era algo excepcional. Nos relatos de várias testemunhas inquiridas em algumas devassas, aparecem escravos que conversavam em casa de homens forros na vila; que paravam em casa a£, outro senhor para trocar algumas palavras com suas escravas ou beber um pouco de aguardente antes de continuar o seu caminho ou que, até mesmo, deixavam a fazenda, passando o domingo na vila. Outros depoimentos indicam que algumas tarefas impostas pelos senhores implicavam, necessariamente, que os escravos saíssem da fazenda, andando pelos caminhos e estradas. Numa devassa, há ainda menção de um grupo de mais de doze escravos que, numa noite do mês agosto, andavam bêbados pelo caminho do sertão do Nogueira, fazendo alarios e desordens enquanto se dirigiam para a fazenda de seu senhor. ${ }^{23}$
}

Estes casos nos fazem pensar na relativização da dominação senhorial, uma vez que o escravo, distanciado fisicamente de seu senhor ou feitor e da unidade de produção a que estava ligado, poderia gozar, de certa forma, de uma liberdade; poderiam executar opções pessoais que escapavam ao controle do senhor. O que mais impressiona não é a existência destas "liberdades" no cotidiano das relações senhor-escravo, mas principalmente que estes escravos voltavam as fazendas e casas senhoriais. Existia, desta forma, no caráter da dominação senhorial sobre os escravos algo que ia além da relação pessoal propriamente dita e que relegava o escravo à submissão mesmo quando ele se encontrava longe da presença direta de seu senhor. Na verdade, havia todo um universo de relações pessoais que se encarregava de identificar o cativo e reafirmar a sua condição, fazendo eles se recordarem quem era o seu senhor e controlando-Ihes as atividades. Os escravos poderiam sair de suas fazendas, mas os laços que os ligavam a seus senhores continuavam firmemente atados e eram minuciosamente vigiados por toda a sociedade.

22 Ibid., p. 13.

23 Op. cit., Campos da Violência ... p. 235. 
O Título XXXIII do Livro I das Ordenações Filipinas mandava que os escravos presos fossem sustentados por seus senhores. Caso estes não lhe dessem de comer, o Carcereiro poderia gastar até $\$ 20$ réis por dia para seu sustento. Em caso de sentença que o livrasse da prisão, o escravo só seria solto depois que o senhor pagasse os ditos gastos, o mesmo ocorrido em caso de morte do escravo. Silvia Lara nos informa ainda que

\begin{abstract}
A lei de 29 de março de 1719 proibia aos mulatos e pretos escravos o uso de facas e outras armas sob pena de 10 anos de galés. Ao que tudo indica, porém, esta determinação não era cumprida. Em 1726, constatava-se não haver branco nem preto que deixe de usar delas, principalmente das facas (...) opondo-se à execução [da lei] circunstância dos escravos, alegando os senhores que não o devem prender, impondo-se a pena de lei de tantos anos para as Galés e só querem que os açoitem no Pelourinho, a arbítrio do Governador, sem auto nem processo "e "que no caso de se executarem a lei nesta Cidade [do Rio de Janeiro] não pode Ter efeito donde dizem que não escusam as facas para abrirem picada no mato e para defenderem das feras" (...) Em 25 de junho de 1749, outra determinação real insistia na proibição do uso de armas por parte dos pretos e mulatos sob pena de galés. Sete anos depois, porém, um Alvará determinou a comutação da pena de Galés pela de "100 açoites, dados no Pelourinho, e repetido por 10 dias alternados"para os pretos e mulatos escravos achados com facas e mais armas proibidas; para os brancos continuavam a ser observadas as galés. ${ }^{24}$
\end{abstract}

A questão que fica evidente aqui, é a necessidade do senhor de ao mesmo tempo lidar com a utilização de facas e facões nos serviços feitos pelos escravos, e cuidar para que não se transformassem em armas. Não se trata meramente do medo de uma população armada, seja ele metropolitano ou senhorial, ou simplesmente a intenção de diminuir o número de mortes e ferimentos. A análise dos processos criminais de Antonina, no que concerte ao uso de armas proibidas, mostra uma íntima ligação entre o cotidiano desses medos e algumas estratégias de controle social.

Nos processos de Campos dos Guaitacases analisados por Lara, com apenas uma exceção, todos os escravos presos por armas proibidas usavam facas. Alguns registros indicam claramente que as facas eram usadas pelos escravos como instrumentos de trabalho: para cortar capim, no serviço de marinheiro, nos trabalhos na casa do senhor. Outros mostram que elas podiam ser presas à cinta e transformar-se em instrumentos de agressão: brigas, ferimentos...

Os Soldados do corpo dos auxiliares perscrutavam a cidade em busca do que poderíamos chamar de pessoas suspeitas: pessoas que apresentavam características que levassem a pensar serem escravas, que procurassem não ser reconhecidas ou que realizavam atos condenáveis (batuques, brigas, etc). O critério da suspeição parece ser, aliás, não só o fundamento desta última instância como também do controle difuso exercido pelos não escravos. No decorrer do séc. XIX, pelo menos nas cidades, a suspeição é mais generalizada: era toda uma massa de indivíduos que era suspeita todo o tempo. Enquanto suspeição generalizada e contínua, tomava-se o próprio núcleo da estratégia geral de controle social.

\title{
A escravidão perde sua legitimidade
}


Nos processos criminais que analisei encontrei três casos de mortes de negros que foram consideradas suicídios. O primeiro caso data do ano de 1861, neste processo é encontrado morto, enforcado por uma corda de mucunã, na Graciosa, no pé do estaleiro, o preto de nome José, escravo do Doutor Manoel Alves de Araújo. A primeira testemunha é Joaquim Manoel Pacheco, 30 anos de idade mais ou menos, profissão de seus negócios, casado, natural de Paranaguá e morador nesta cidade. Foi-lhe perguntado se havia algum ferimento no escravo, respondeu que não. Se sabia qual o motivo da morte, respondeu que não sabia. Se sabia como tinha morrido, respondeu que enforcado em uma corda de mucuña ${ }^{25}$.

As outras testemunhas vão dar seus depoimentos neste mesmo sentido, todas estavam convencidas que a morte do escravo devia-se ao fato dele mesmo ter se enforcado com uma corda de mucuña. O negociante Daniel Nicolau Benedito, em seu depoimento fala que estava convencido de que ele mesmo havia se enforcado porque dizia por várias vezes que o havia de fazer. ${ }^{26}$ Porém, o motivo pelo qual o escravo iria se matar não foi esclarecido pela testemunha. O que é muito interessante notar neste processo é a naturalidade e a certeza com que as pessoas encaram o fato do escravo ter se enforcado, mesmo que o motivo não seja aparente. Este é um indício que aponta para a descrença e consequente perda de legitimidade da escravidão.

Os outros dois processos relativos a morte de negros considerados como suicídio datam do ano de 1865 e não contam com mais de cinco folhas cada um, são processos muito curtos onde não aparecem nem mesmo testemunhas. No auto de corpo delito realizado no cadáver da preta liberta Maria a justiça chega à conclusão que a causa da morte foi asfixia por submersão e o processo é concluído da seguinte maneira: Visto que o auto de corpo delito feito no cadáver da preta liberta Maria julgo improcedente a Municipalidade pagar as custas. ${ }^{27}$

O Auto de corpo delito feito no cadáver de Domingos, escravo de Joaquim de Castro dá como causa da morte também asfixia por submersão ${ }^{28}$. A conclusão doeste processo se parece muito com a do anterior, salvo que neste caso aparece envolvida a pessoa do senhor, que deverá se responsabilizar pelos custos pois, segundo a justiça, foi ele quem trouxe o cadáver para nele se proceder a esta formalidade. Me parece muito estranho uma pessoa se matar afogada se bem que, o que nos interessa aqui não é esta questão, mas sim a da perda da legitimidade da escravidão. Porque se a instituição da escravidão fosse realmente encarada como legítima, tanto por senhores e escravos como pelas autoridades, não existiriam razões palpáveis para um escravo cometer o suicídio. O que é muito interessante notar ainda é que estes processos tenham acontecido em datas tão próximas e que a única preocupação da justiça, nos três casos, parece ser com o pagamento dos custos dos processos.

A historiadora Silvia Lara em seu livro Campos da Violência nos conta

25 Fórum Luis Silva e Albuquerque. Auto de Corpo de Delito feito no cadáver do escravo José. Ano: 1861, maço : 1860-1870, p.3.

26 Ibid., p.4.

27 Fórum Luis Silva e Albuquerque. Auto de Corpo de Delito feito no cadáver da preta liberta Maria. Ano: 1865, maço: 1860-1870, p.3.

28 Fórum Luis Silva e Albuquerque. Auto de Corpo de Delito feito no cadáver do escravo Domingos. Ano: 1865, maço : 1860-1870.

96 
do caso de um escravo que era muito revoltoso e que fugira levando todos para o mato. Ele foi preso e submetido a açoites por três dias consecutivos e no dia seguinte foi encontrado degolado e com uma navalha junto a si. O caso foi considerado de suicídio. Nenhuma das testemunhas questionou os atos do feitor, e teve um lavrador que chegou mesmo a afirmar que Joaquim tinha tido a maldade de cortar a própria garganta. ${ }^{29}$ Outra devassa também não culpou ninguém pelo suicídio de um escravo chamado Manoel. Ele foi achado enforcado num ramo baixo de ingazeira. Assim como outras testemunhas inquiridas, um lavrador da região afirmou que o negro (...) andava fugido de seu senhor e sendo apanhado o mesmo senhor o castigara e deitou-lhe grilhões aos pés e que o dito negro fugira e se enforcara. ${ }^{30}$

Outros casos de devassa acabam por julgar o caso suicídio, sem culpar pessoa alguma. Não podemos afirmar que estes acontecimentos eram freqüentes, mas o que fica em evidência é que mesmo em casos como estes não surgiu nenhuma palavra condenando o ato de castigar. É muito revelador o quanto tais práticas eram aceitas no mundo senhorial. O suicídio praticado pelos escravos aparece caracterizado, nessas devassas, como fruto de paixão, uma maldade praticada por um ser revoltoso. ${ }^{31}$ É justamente nos casos de morte que não se chegou a achar os culpados. Segundo Silvia Lara

\begin{abstract}
Estes dados podem indicar que a ação judicial se fazia menos eficiente quanto maior a gravidade do delito. Por outro lado, indicam ainda que, em relação aos atos e confrontos considerados criminosos, a interferência judicial se fazia menos no sentido de punição do criminoso em si e mais no sentido de reparação dos danos advindos do delito. ${ }^{32}$
\end{abstract}

Geralmente, em delitos de menor gravidade e prejuízo que a morte, a ação da justiça se fez mais eficiente e os interesses de ressarcimento dos danos moviam as próprias vítimas ou senhores das vítimas escravas a empreender 0 processo e pressionar a justiça a encontrar o culpado.

Em meio aos poeirentos maços de processos encontrei um outro caso que se refere a morte de um escravo. A acusação é que (...) tinha chegado havia alguns anos João Antônio de Mello deste distrito assassinado a pauladas o escravo ou moleque de nome Sebastião no sítio Boa Vista e mandado enterrar o cadáver do mesmo por escravos seus no mato no referido sítio. ${ }^{33}$ Foi então feito um interrogatório ao réu João Antônio de Mello, casado, 56 anos, lavrador com engenhos de socas de arroz e olaria, nascido em Portugal

\footnotetext{
perguntado se ele, réu, tinha um escravo de nome Sebastião respondeu que não, que de nome Sebastião não, que fazem bastante anos que teve em seu poder um moleque recebido do Comendador Manoel Antônio Guimarães, da cidade de Paranaguá por transações. Perguntado qual o nome que destinava ao dito moleque respondeu que esperava que depois que o recebeu do mencionado Comendador (...) que passou cinco ou seis meses para o batizar na Matriz desta cidade que para este fim já se tinha entendido com o reverendo Vigário da mesma Matriz, que até então só aludia o nome de moleque novo pelo qual era tratado por toda a família. (...) Perguntado
}

29 Op. cit., Campos da violência..., p.61-62.

30 Ibid., p.62.

31 Ibid., p.63.

32 Ibid., p.273.

33 Fórum Luis Silva e Albuquerque. Auto crime. Réu: João Antônio de Mello. Autor: Antônio Manoel Bicudo. Ano: 1861, maço : 1860-1870, p.2. 
qual o destino que havia dado a tal moleque respondeu que passado três meses que o havia recebido Ihe deu uma moléstia. ${ }^{34}$

O réu fala ainda em sua defesa que o moleque fica doente e que um dia quando estava na roça de mandioca, no caminho do sítio Boa Vista, com os demais parceiros, foi acometido de uma forte dor de barriga. Foi mandado levá-lo até a casa e foi chamada Anna Domingas para curá-lo. Depois de quatro dias o moleque morreu. O réu diz que mandou então avisar o vigário que o respondeu em uma carta que pagão não se sepultava no sagrado, e que mandou enterrá-lo lá no sítio mesmo, em qualquer parte, porque no Sagrado era uma irregularidade completa enterrar um pagão, o que foi feito pelo réu.

Nota-se nitidamente no depoimento do senhor a preocupação em se explicar quanto ao batismo do escravo. O Batismo é um problema que se coloca como uma constante preocupação do português ao entrar em contato com o índio e o africano utilizado como mão de obra. A conversão era fundamental e era crime adotar outras crenças ou simpatizar com elas, pois isto implicaria num desequilíbrio das próprias bases do sistema de vida, o que não podia ser aceito. Muitos eram os motivos que levavam ao batismo o africano. Segundo Scarano

\begin{abstract}
Em todo o Brasil eram seguidas as regras contidas nas Constituições primeiras do Arcebispado da Bahia, baseadas nas que fixara o Concílio Tridentino, onde se exigia do neófito conhecimento da Doutrina Cristã e aquiescência ao batismo para os maiores de sete anos. A exigência estendia-se aos escravos, que eram tidos, portanto, como seres racionais e humanos. Os batismos de recém-chegados só poderiam realizar-se quando eles conhecessem a língua, ou pudessem entender-se por meio de intérpretes. As perguntas eram simplificadas, vazadas em linguagem quase infantil: "Botas fora de tua alma todos os teus pecados? Queres ser filho de Deus?" E outras do mesmo teor. ${ }^{35}$
\end{abstract}

Neste sentido, propiciar o batizado às crianças escravas era um dever social e religioso dos senhores. A Coroa portuguesa, apoiada nas bulas papais, tendeu a justificar a escravização dos africanos com base no proselitismo e catequese. O tema continuou presente também em relação aos africanos cativos. Nas Ordenações Manuelinas, promulgadas em 1521, e nas Filipinas, de 1603, há títulos específicos, no Livro $V$, que mandavam que os possuidores de escravos da Guiné os batizassem até seis meses depois do dia em que tivessem caído sob o seu poder, sob pena de perda do escravo para quem os denunciasse. ${ }^{36}$

Voltando ao processo, a justiça tratou então de procurar o corpo do moleque. Foi feito um Auto de Exumação onde o escravo Feliciano, um dos escravos que enterraram o moleque, indicou o local onde provavelmente estaria o corpo de Sebastião. Disse que segundo sua lembrança era em uma baixada que apontou junto a uma grande pedra na beirada do caminho do porto do dito sítio ou em uma outra baixada do outro lado do mesmo caminho. Depois de muitas buscas nada foi encontrado, ou Feliciano tinha memória curta ou se senhor, João Antônio de Mello, tratou logo de encurtá-la.

34 Ibid., p.4-5.

35 SEBASTIÃO MONTEIRO DA VIDE, Constituições do Arcebispado da Bahia, São Paulo: Typografia 2 de Dezembro, 1853. Apud., op. cit, Devoção e escravidão...pp.60-61.

36 Op. cit., Campos da Violência..., p. 2216-217.

98

Qevista \$ernáculo 

cimento, homem branco, casado, 40 anos, vive de seus negócios, morador natural de Antonina:

Perguntado se sabia que o réu possuía um moleque de nome Sebastião. Respondeu que sabia que ele possuía este moleque porque foi sócio do réu nesse tempo, em um engenho de soque no sítio Pinheirinho. Perguntado se a testemunha sabia onde residia o moleque. Respondeu que Ihe constava ter morrido a muito tempo, e que isso sabe por boca do próprio réu. Perguntado se ele sabia se a morte do dito moleque tinha sido proveniente de pancadas dadas pelo réu no dito moleque. Respondeu que ouvira dizer a Mariana Roza Teixeira ter sido esta morte proveniente de pancadas dadas pelo réu no moleque. Se sabia onde tinha sido enterrado. Que havia sido enterrado no sítio Boa Vista, tendo ouvido isso da boca do próprio réu. ${ }^{37}$

A referida Mariana Roza, brasileira, solteira, 40 anos mais ou menos, vive de lavoura, moradora natural de Antonina, também nos dá sua testemunha:

\begin{abstract}
Perguntado se sabia do crime. Disse que vindo ela em companhia de Jesuino Amado do nascimento e de uma parda de nome Antonia, já falecida, da casa de uma vizinha (...) em uma roça na beira do caminho no sítio chamado Boa Vista, viu com seu companheiro estar o réu espancando o referido moleque, e que no dia seguinte ouvira dizer a uma escrava do réu que o moleque tinha morrido e que os ratos tinham comido os beiços e nariz do mesmo moleque e que isso ela mesma testemunha já havia dito em uma ocasião ao próprio réu (... $)^{38}$
\end{abstract}

Foi alegado que a testemunha de Mariana Roza não era válida porque ela era inimiga do réu já tendo a história de um processo crime contra o réu por motivo de propriedade, e que o fizera por vingança. No processo consta que esta testemunha é mais uma prova da inocência do réu. Realmente parece que havia um grande interesse em inocentar o acusado João Antônio de Mello. Na sequência do processo percebe-se claramente isso com o depoimento das outras testemunhas que procuram a todo custo defender o réu. A testemunha Antônio Alves de Souza falou que

(...) sabia que o réu tinha um escravo que faleceu no ano de 1849 não se lembrando nem o mês nem o dia do seu falecimento pois já havia se passado 11 anos, que o moleque morreu de moléstia proveniente de comer terra. (...) Disse que foi enterrado no sítio pois era pagão e não poderia ser enterrado no Sagrado. ${ }^{39}$

A conclusão do processo é que a morte do moleque Sebastião foi devido a uma moléstia.

Coincidentemente, em minhas buscas no Departamento de Arquivo Público, acabei encontrando um Ofício que se refere a esse processo:

(...) ao que diz o Subdelegado de Polícia desta cidade acerca do assassinato cometido por João Antônio de Mello passo a informar a V. Exa o seguinte: João Antônio de Mello foi preso pelo Subdelegado de Polícia desta cidade (...) no dia 6 de junho do corrente ano por ele constar Ter assassinado a alguns anos a esta parte um escravo de sua propriedade e cujo processo correu na mesma Subdelegada; porém estando a finalizar-se, foi requerido pelo réu a prescrição do crime, e obteve por Ter provado (talvez de combinação com as testemunhas) Ter passado os

37 Fórum Luis Silva e Albuquerque. Auto crime. Réu: João Antônio de Mello. Autor: Antônio Manoel Bicudo. Ano: 1861, maço : 1860-1870, p. 14.

38 Ibid., p. 15.

39 Ibid., p. 18. 
anos que marca a lei ,e imediatamente foi solto requerendo perdas e danos que diz a autoridade Ihe causou. ${ }^{40}$

Aqui vemos uma clara disputa entre o poder do senhor e o poder da Justiça. Os senhores de escravos muitas vezes não admitiam a interferência da Justiça em seus negócios, principalmente quando essa interferência implicava em algo tão sério como a possibilidade de ser preso por uma acusação de assassinato.

É bem sabido que alguns senhores supliciavam seus escravos até a morte. Cabe aqui lembrarmos algo para o qual Chalhoub nos alertou:

\begin{abstract}
Numa época em que a legitimidade da instituição da escravidão era abertamente questionada, e sua existência se justificava normalmente em termos da necessidade de evitar o hipotético caos econômico que resultaria de sua abolição a curto prazo, havia menos tolerância na Corte em relação as Senhores que insistiam em suplicar seus escravos. A escravidão se tornava agora um problema de consciência, e havia um sentimento de culpa relativamente generalizado na sociedade..$^{41}$
\end{abstract}

\title{
A morte do senhor
}

É bem sabido que a morte do senhor era um momento de muita tensão na vida dos escravos, principalmente se estes eram suspeitos de tal morte. Seus destinos a partir de então seria incerto, poderiam parar nas mãos de um senhor com todo um novo cortejo de caprichos e vontades. O mais complicado ainda era fazerem valer todos os direitos conquistados ao antigo senhor. Viam-se ameaçados também de serem separados de seus familiares e de seus companheiros de cativeiro.

Em Antonina ocorreu um caso bem sui generis de morte de um senhor, era o ano do Nascimento de Nosso Senhor Jesus Cristo de 1862. Vinha o falecido Alferes Joaquim José da Roza, acompanhado de mais três escravos seus, descendo o rio da cachoeira em uma embarcação carregada de madeira quando caiu na água e morreu afogado. Faustino, Caetano e Antônio (os escravos que estavam na embarcação) foram logo vistos como suspeitos da morte.

A testemunha José Dias, 35 anos, casado, natural desta cidade e morador do rio da cachoeira, lavrador diz que

(...) ouvindo uns gritos no rio acudiu a eles e ai encontrou dois escravos do falecido, e um outro dito do mesmo, no barranco do mesmo rio, perguntando o que tinha acontecido estes Ihe responderam que um pau que eslava arcado sobre o rio tinha lançado o seu senhor na água e que ele escravo que estava no barranco tinha caído na água para ver se salvava o seu senhor. ${ }^{42}$

Faustino, escravo de Dona Maria Francisca de Paula, 30 anos mais ou menos, solteiro, lavrador, natural da Costa da Africa dá seu depoimento como testemunha informante*:

40 DEAP. Ofício. Ap. $n^{\circ} 119$, p. 359-360.

41 Op. cit., Visões da liberdade..., p.204.

42 Fórum Luis Silva e Albuquerque. Auto crime. Réus: Antônio, Caetano e Faustino. Autor: Justiça. Ano: 1862, maço : 1860-1870, p.5.

* Em todos os processos que examinei, quando os escravos aparecem como testemunhas, é sempre como 


\begin{abstract}
Perguntado se tinha amizade ou inimizade com o Alferes Joaquim José da Roza já falecido. Respondeu que tinha amizade e que era o seu senhor moço e que sabia que o mesmo era morto(...) porque vinha com ele na canoa. Perguntado como morreu. Respondeu que vindo com ele para essa cidade em uma volta do rio defronte o Limoeiro um pau o atirou da canoa na ocasião de virar a volta, a água do monte meteu a canoa por baixo do pau que estava debruçado sobre a água do rio, e daí resultou morrer afogado apesar de um de seus parceiros botar-se à água para salvar o seu senhor, contudo não foi possível salvá-lo em razão de estar o rio muito cheio e furioso. Perguntado a razão de porque o senhor moço não se defender do pau. Respondeu que vindo a canoa sobrecarregada além disso muito mais de milho por cima, aonde seu senhor moço vinha sentado em cima, por isso é que não pode desviar-se deste pau. ${ }^{43}$
\end{abstract}

Caetano, escravo do falecido, 32 anos, solteiro, natural da Africa, lavrador fala que (...) atirou-se na água para salvar o seu senhor e apesar de o segurar não pode em consequência de o rio estar muito cheio e furioso e o seu senhor o ter segurado em um braço ficando por esta forma privado de poder sacudir-se e para também não morrer com ele teve de tirar a camisa e deixa-la na mão de seu senhor ${ }^{44}$.

Isto nos revela algo para se pensar, ao investigar o processo percebemos que a autoridade se preocupou em perguntar para todas as testemunhas se os escravos tentaram salvar seu senhor. Realmente, Caetano supostamente pulou na água para salvar a vida de seu senhor, mas no momento em que viu ameaçada sua própria vida, tratou logo de se livrar do senhor que o puxava pelo braço.

É interrogada ainda a esposa do falecido, Joaquina Caetana da Roza (...) Perguntado se havia entre os escravos e seu finado marido alguma rixa antecedente e mesmo na ocasião do embarque. Respondeu que não. Perguntado se atribuía que os escravos fizessem parte da morte. Respondeu que não sabia (... $)^{45}$

Este processo é mais uma prova de que reinava naquele tempo uma grande desconfiança e um enorme medo e insegurança em relação ao comportamento e atitudes dos cativos. Um medo calado e igualmente corrosivo de que os negros pudessem agir coletivamente e matar um senhor que considerassem injusto, que castigasse injustamente. Talvez este seja mais um indício da perda de legitimidade da escravidão, pois se este sistema realmente fosse completamente aceito e legítimo, como o queriam as elites da época e as autoridades, e se as pessoas daquela sociedade acreditassem verdadeiramente nele, este medo não teria fundamento.

\title{
Muitas inquietações, poucas certezas
}

Muito mais do que conclusões, estas páginas pelas quais o leitor acaba caminhar procuram demonstrar inquietações. A violência, que aparece claramente em todos os processos investigados, não constitui uma característica distintiva da sociedade escravista. Aqui cabe lembrar algo para o qual Silvia Lara nos alertou

testemunha informante.

43 Fórum Luis Silva e Albuquerque. Auto criminal. Réus: Antônio, Caetano e Faustino. Autor: Justiça. Ano: 1862, maço : 1860-1870, p.Il.

44 Ibid., p.12.

45 Ibid., p. 13.

Qevista Bernáculo 
Atribuir "violência" ao escravo não explica coisa alguma, ou melhor, exprime o óbvio, com desvantagem de sermos induzidos a pensar que, nas sociedades contemporâneas, a estratégia de reprodução das relações desiguais não são violentas. Mais que um procedimento analítico, explicativo ou meramente descritivo das estratégias de controle social, a utilização do termo "violência " é questão de percepção política. Neste sentido, deve ser enunciada em e por princípio como essência das sociedades desiguais e não apenas como elemento constitutivo de uma dominação de classe específica. Por isso mesmo, sua utilidade como explicação das relações entre senhores e escravos deve ser questionada. ${ }^{46}$

Desta maneira, não seria mais interessante recuperar os escravos não como vítimas, mas como agentes históricos? Devemos estar atentos para o fato de que o discurso da vitimização pode ser o discurso da denúncia, mas, ao mesmo tempo, pode ser o discurso do escritor insensível ao potencial político do outro, do diferente.

Remexemos, portanto, práticas, costumes, lutas, resistências, acomodações e solidariedades presentes no cotidiano daqueles homens e mulheres de Antonina na segunda metade do séc. XIX. Deparamo-nos com homens e mulheres em movimento, pondo e dispondo sobre suas vidas, fazendo escolhas, vivendo e construindo suas relações de forma variada e múltipla. E é justamente nesta complexa relação entre o discurso do historiador e os vários discursos do passado que encontramos a possibilidade de fazer história, de construir o saber histórico.

Diferente das construções censuradoras a respeito do comportamento dos escravos, procurei descobrir as suas próprias versões ou leituras sobre determinados momentos de sua experiência de vida. Para tal, consultei processos criminais que constituem documentos singulares onde é possível detectar a fala e os significados dos gestos dos escravos em momentos de tensões e conflitos na relação com seus senhores e proprietários. Através deste trabalho busquei demonstrar que estes escravos longe de serem somente seres passivos e inertes aos acontecimentos que fazem parte de seu cotidiano, mostraram-se muitas vezes astutos e humanos. Desta maneira o escravo é visto como sujeito social, de certa maneira condicionados pelo meio social em que viveram mas igualmente influenciando este mesmo meio. Portanto, os cativos não são encarados como vítimas de uma situação, mas como pessoas, que como outras, foram capazes de deixar as marcas de sua existência, criando gestos e valores que serviram para tornar mais aceitável a dura experiência do cativeiro.

A análise do comportamento de escravos e senhores nestas microsituações de conflito e luta social foram reveladoras no sentido de enriquecer o embate entre visões e representações muito diversas e estratégias de negociação muito sutis onde

(...) tanto os senhores quanto os escravos adotaram faces, máscaras e atitudes ambíguas, a fim de preservarem seus interesses em jogo(...)no jogo social representado pelo universo conflitivo da escravidão, os cativos jamais foram vítimas dos atos e valores que praticaram. Foram, sim, exímios atores sociais- no sentido mesmo que esta expressão possuí de teatralidade- medindo e escolhendo os momentos oportunos de se antagonizarem e de se adequarem astutamente aos valores e normas impostas a seu cotidiano. ${ }^{47}$

46 Op. cit, Campos da violência..., p.354.

47 PENA, E. S. O jogo da face: a astúcia escrava frente aos senhores e à lei na Curitiba provincial.

Curitiba: Aos Quatro Ventos, 1999. p.12. 
Chalhoub nos alerta para a potencialidade deste tipo de documento na investigação das formas de controle social espalhadas nas relações cotidianas dos escravos, mas também para a sua potencialidade na análise das formas e estilos de luta e resistência às manifestações deste controle. Se um processo representa, por um lado, a efetivação de um tipo de controle- um verdadeiro exercício de esquadrinhamento dissecando a fundo a vida dos populares e impondo regras e padrões de conduta preestabelecidos elaborados por juizes e delegados de polícia, por outro lado, ele revela atitudes de afrontamento e não de adequação àquelas imposições. Ao ler e reler o conteúdo de muitos processos criminais, o historiador vai tomando consciência dos paradoxos e ambigüidades que cercam as dimensões do controle social. Chalhoub ainda nos chama a atenção para que o grande desafio do historiador interessado em fuxicar este tipo de documentação é deparar-se com trechos nebulosos, cujo significado só será esclarecido depois de diversas tentativas de interpretação.

\footnotetext{
Os momentos de opacidade e de silêncio, que porventura apresentam-se no conteúdo de alguns desses processos, serão momentos privilegiados que, uma vez desvendados, poderão elucidar muitas questões a respeito de consciência e dos gestos praticados pelas pessoas envolvidas. Enfrentar o opaco pode ser mais vantajoso e mais gratificante para a pesquisa histórica do que a mera descrição daquilo que se apresenta de forma já segura e transparente. ${ }^{48}$
}

Desta forma, o que interessa não é o que realmente se passou, mas a reflexão sobre as diferentes versões produzida pelos agentes sociais envolvidos em cada processo, procurando interpretar os seus significados. É ainda interessante salientar que cabe ao historiador buscar reunir tudo o que se repete sistematicamente em meio à enorme quantidade de evidências colocadas pelos processos-crime. A análise da repetição é fundamental para que o historiador enriqueça a sua investigação pelo foco das lutas sociais. Porém o historiador deve estar igualmente atento para as situações singulares, ou seja, para todo o contexto atípico. É Darnton quem nos alerta para esta questão, enfatizando que várias vezes é na atipicidade de um evento que é possível deparar com vestígios que iluminem o nosso entendimento sobre o mundo e as pessoas que estamos investigando.

Muito diferente da visão de escravos bestializados, coisificados e infantilizados presente nas falas da autoridade pública, dos romances, dos jornais, dos juristas e emancipacionistas e igualmente de pesquisadores mais recentes, os processos nos dão acesso a uma visão onde afloram os gestos e atitudes de astúcia de escravos que estavam dentro de um cotidiano de pequenos conflitos com seus senhores. O que me incentivou a perscrutar a poeirenta documentação cartorial foi a procura, mergulhada neste mundo de violência, dos comportamentos destes escravos, que não pareciam ser de maneira alguma passivos e submissos. Mas que atuaram e interferiram oportunamente no rumo de suas vidas, mostrandose sujeitos constituidores de sua própria história. Na verdade, o cativo brigava por brechas e espaços de liberdade em uma sociedade que o sufocava.

Ao privilegiar esta busca nos processos criminais procurei justamente 
desvendar a própria leitura e interpretação dos escravos sobre os acontecimentos que os cercavam e ligavam diretamente ao senhor ou à autoridade policial, e também notando que a criação e a recriação destas versões distintas sobre a experiência escrava eram intimamente ligadas ao jogo do conflito e das lutas sociais da escravidão. No Brasil oitocentista muitos escravos viveram momentos muito intensos, onde foram levados a reverem suas próprias condições, tomando atitudes diretas ou sutis que, mesmo não tendo um caráter explícito, mostraram uma postura digna e uma astúcia corriqueira que devem ser observadas pelos historiadores. Neste sentido devemos lembrar de Benjamin que nos alertou: articular historicamente o passado não significa conhecê-lo como ele de fato foi. Significa apropriar-se de uma reminiscência, tal como ela relampeja no momento de perigo..$^{49}$ Acredito, como Spiller, que na busca desses pequenos e significativos atos políticos de escravos encontramos a possibilidade de iluminar alguns significados políticos de confrontação e divergência. É interessante notar que não foram somente as atitudes explícitas de recusa ao cativeiro que demonstraram ser práticas conscientes de resistência por parte dos cativos, existiram outras estratégias menos diretas, mas não menos eficientes, que rechearam o seu cotidiano das relações escravistas.

\section{Fontes e referências}

\section{Fontes manuscritas citadas}

1- Processos criminais pesquisados no Fórum Luis Silva e Albuquerque (Antonina):

Auto crime. Réu : Antônio Corrêa. Autor : Justiça. Ano : 1859, maço : 1850-1860.

Auto crime. Réu: Geronimo Fernandes Braga. Autor: Jesuino Amado do Nascimento. Ano : 1859: maço 1850-1860.

Auto crime. Réu : Teles. Autor : Justiça. Ano: 1869, maço: 1860-1870.

Auto de Corpo de Delito feito no cadáver do escravo José. Ano: 1861, maço : 18601870.

Auto de Corpo de Delito feito no cadáver da preta liberta Maria. Ano: 1865, maço: 1860-1870.

Auto de Corpo de Delito feito no cadáver do escravo Domingos. Ano: 1865, maço : 1860-1870.

Auto crime. Réu: João Antônio de Mello. Autor: Antônio Manoel Bicudo. Ano: 1861, maço : 1860-1870.

2- Ofícios pesquisados no Departamento de Arquivo Público do Paraná:

Livro 69, Officio da Camara Municipal da Cidade de Antonina enviada pelo seu Suplente Joaquim Leite Mendes ao Presidente de Província Francisco Liberato de Mattos, ANO : 1859.

Livro 73, p.244. Ano: 1859

Livro 69, p.47. Ano: 1859

49 BENJAMIN, W. Sobre o conceito de história. In: Obras escolhidas. Magia e técnica, arte e política: ensaios sobre literatura e história da cultura. São Paulo: Brasiliense, 1985, v. 1, p.224. 


\section{Fontes impressas}

Jornal Dezenove de Dezembro, 29 de janeiro de 1859.

\section{Bibliografia}

AZEVEDO, C. M. Onda negra, medo branco: o negro no imaginário das elites-séc. XIX. Rio de Janeiro, Paz e Terra, 1987.

BAKHTIN, M. A cultura popular na idade média e no renascimento: o contexto de François Rabelais. Brasília: Editora da Universidade de Brasília, 1993.

BASTIDE, R. As religiões africanas no Brasil. São Paulo : Editora da Universidade de São Paulo, 1960.

BENJAMIN, W. Magia e técnica, arte e política: ensaios sobre a literatura e a história da cultura. São Paulo : Brasiliense, 1994.

BOSCHI, C. C. Os leigos e o poder: irmandades leigas e política colonizadora em Minas Gerais. São Paulo : Ática, 1986.

BURKE, P. Cultura popular na Idade Moderna. São Paulo: Cia. das Letras, 1989.

CARNEIRO, E. Crioulos e ladinos: estudos sobre o negro no Brasil. Rio de Janeiro: Civilização Brasileira, 1964.

CASTRO ALVES, A. de. Os escravos. São Paulo : Martins, 1972.

CASTRO, H. M. Das cores do silêncio. Rio de Janeiro: Arquivo Nacional, 1995.

CHALHOUB, S. Visões da liberdade: uma história das últimas décadas da escravidão na Corte. São, Paulo: Companhia das Letras, 1990.

. Trabalho, lar e botequim: o cotidiano dos trabalhadores no Rio de Janeiro na Belle Époque. São Paulo: Brasiliense, 1986.

. Visões da liberdade: senhores, escravos e abolicionistas da Corte nas últimas décadas da escravidão. In: História: questões e debates, $\mathrm{n}^{\circ} 16$, junho. AP AH, 1988.

DARNTON, R. O beijo de Lamourette: mídia, cultura e revolução. São Paulo: Companhia das Letras, 1990.

. O grande massacre de gatos: e outros episódios da história cultural francesa. Rio de Janeiro: Graal, 1988.

FERNANDES, J. L. Congadas paranaenses. Rio de Janeiro: FUNARTE, 1977.

FERRARINI, S. A escravidão negra na província do Paraná. Curitiba: Editora LíteroTécnica, 1971.

FRANCO, M. S. C. Homens livres na ordem escravocrata. São Paulo: Ática, 1974.

FREYRE, G. Casa-grande e senzala: formação da família brasileira sob o regime da economia patriarcal. Rio de Janeiro : Record, 1998.

GEBARA, A. O mercado de trabalho livre no Brasil: 1871-1888. São Paulo: Brasiliense, 1986.

GEERTZ, C. A interpretação das culturas. Rio de Janeiro: Editora Guanabara 
Koogan S.A., 1989.

GENOVESE, E. D. A terra prometida: o mundo que os escravos criaram. Rio de Janeiro: Paz e Terra, 1988.

GINZBURG, C. Mitos, emblemas, sinais: morfologia e história. São Paulo: Cia. Das Letras, 1989.

. O queijo e os vermes: as crenças e idéias de um moleiro perseguido pela inquisição. São Paulo: Cia. Das Letras, 1989.

GIRARDELLI, E. C. Ternos de Congos: Atibaia. Rio de Janeiro: MEC-SEC-FUNARTE, 1981.

GOMES, F. S. (Org.). Liberdade por um fio: história dos quilombos no Brasil. São Paulo: Cia. Das Letras, 1996.

GOULART, J. A. Da fuga ao suicídio : aspectos da rebeldia dos escravos no Brasil. Rio de Janeiro : Conquista, INL, 1972.

GUTIERREZ, H. Crioulos e africanos no Paraná : 1798-1830. In : Revista brasileira de história, São Paulo, n 16, p. 161-188, ago, 1988.

HOLANDA, S. B. Raízes do Brasil. São Paulo: Cia. Das Letras, 1995.

LARA, S.H. Campos da violência: escravos e senhores na Capitania do Rio de Janeiro, 1750-1808. Rio de Janeiro: Paz e Terra, 1988.

LEÃO, E. A. Antonina, factos e homens: da edade archeolithica à elevação da cidade. Curitiba: Secretaria de Estado da Cultura, 1999.

LIMA, C. A. M. Em certa corporação : politizando convivências em irmandades negras no Brasil escravista (1700-1850). In : História Questões e Debates, Curitiba, $n^{\circ} 30$, p. 11-38,jan./jun. 1999.

MATOS, H. M. Das cores do Silêncio: os significados da liberdade no sudeste escravista. Brasil, séc. XIX. Rio de Janeiro: Nova Fronteira, 1998.

MATTOSO, K. Q. Ser escravo no Brasil São Paulo: Editora brasiliense, 1981;

REIS, João José. A morte é uma festa: ritos fúnebres e revolta popular no Brasil do séc. XIX. São Paulo: Companhia das Letras, 1991.

MORAES, E. A escravidão africana no Brasil: das origens à extinção. Brasília : Editora da Universidade de Brasília, 1986.

MOURA, C. Quilombos : resistência ao escravismo. São Paulo : Ática, 1987.

NODARI, E.; PEDRO, J. M.; IOKOI, Z. M. G. (organizadoras). História: fronteiras. São Paulo: Humanitas/ FFLCH USP: ANPHU, 1999.

PENA, E. S. O jogo da face: a astúcia escrava frente aos senhores e à lei na Curitiba provincial. Curitiba : Aos Quatro ventos

PEREIRA, M. R. M. Semeando iras rumo ao progresso: ordenamento jurídico e econômico da sociedade paranaense, 1829-1889. Curitiba : Editora da UFPR, 1996.

REIS, J. J. A morte é uma festa: ritos fúnebres e revolta popular no Brasil do séc. XIX. São Paulo: Companhia das Letras, 1991.

. Rebelião escrava no Brasil: a história do levante dos malês (1835). São Paulo: Brasiliense, 1986. 
SCARANO, J. Devoção e escravidão: a irmandade de Nossa Senhora do Rosário dos pretos no distrito Diamantino no século XVIII. São Paulo: Conselho Estadual de Cultura, 1975.

SILVA, E. Dom Obá d'África, o príncipe do povo: vida, tempo e pensamento de um homem livre de cor. São Paulo: Cia. Das Letras, 1997.

Negociação e conflito: a resistência negra no Brasil escravista. São Paulo: Companhia das Letras, 1989.

SOUSA, J. P. (org.). Escravidão: ofícios e liberdade. Rio de Janeiro: Arquivo Público do Estado do Rio de Janeiro.- APERJ, 1998.

THOMPSON, E.P. A formação da classe operária inglesa. Rio de janeiro: Paz e Terra, 1987. 